\title{
Why Do Young Adults Retreat from Marriage? An Easterlin Relative Income Approach
}

\author{
Georgios Mavropoulos, Theodore Panagiotidis
}

\begin{abstract}
Easterlin's relative income hypothesis refers to the current income of young adults compared to the level of material aspirations acquired during childhood. The hypothesis implies that young individuals are expected to reduce fertility if their material aspirations grow at a higher rate than their incomes. This paper examines whether the same hypothesis holds true for marriage. A higher (lower) level of income combined with a lower (higher) level of material aspirations would increase (decrease) relative income and consequently could affect marriage rates. Thus, relative income might be one explanation for the "marriage paradox" which indicates that young adults in the United States retreat from marriage despite perceiving it as a milestone of their lives. One might also expect relative income to be a better predictor of marriage than absolute income. This is because, according to the Easterlin hypothesis, the behaviour of young adults reflects not only their response to changes in external conditions (e.g. absolute income), but also to past events they have experienced.

We employ panel dynamic methods and causality tests for the United States that span the period from 1981 to 2016. Empirical analysis supports the relative income hypothesis. Causality tests indicate that the relationship runs mostly from relative income to marriage rather than the other way round. Relative income emerges as a stronger predictor than absolute income in all of the methods employed.
\end{abstract}

Keywords: Marriage $\cdot$ Relative income $\cdot$ Easterlin hypothesis

\section{Introduction}

The United States (US) has experienced a steady decline in marriage rates over the last half century. According to Martin et al. (2014), one third of young adults in their 20s will never marry. Marriage decline has led to an increase in the share of children born out-of-wedlock and raises concerns over the family structure (Lerman 1996). However, many young men still perceive marriage as one of the most important milestones in their life (Willoughby et al. 2015). This contradiction between the 
observed trend and young men's preference regarding marriage poses a riddle called the "marriage paradox" (Willoughby/James 2017).

Figure 1 shows the percentage decline in marriage rates between 1990 and 2016 in the US. States can be separated into four clusters, with darker states representing a higher decline. States that are coloured white exhibit the lowest decline throughout the examined period, with rates ranging from 8.8 percent to 23.4 percent. The sharpest drop is observed in states with the darkest shade, with rates ranging from 34.86 percent to 71.3 percent.

Fig. 1: The percentage decline of marriage rates across the US between 1990 and 2016

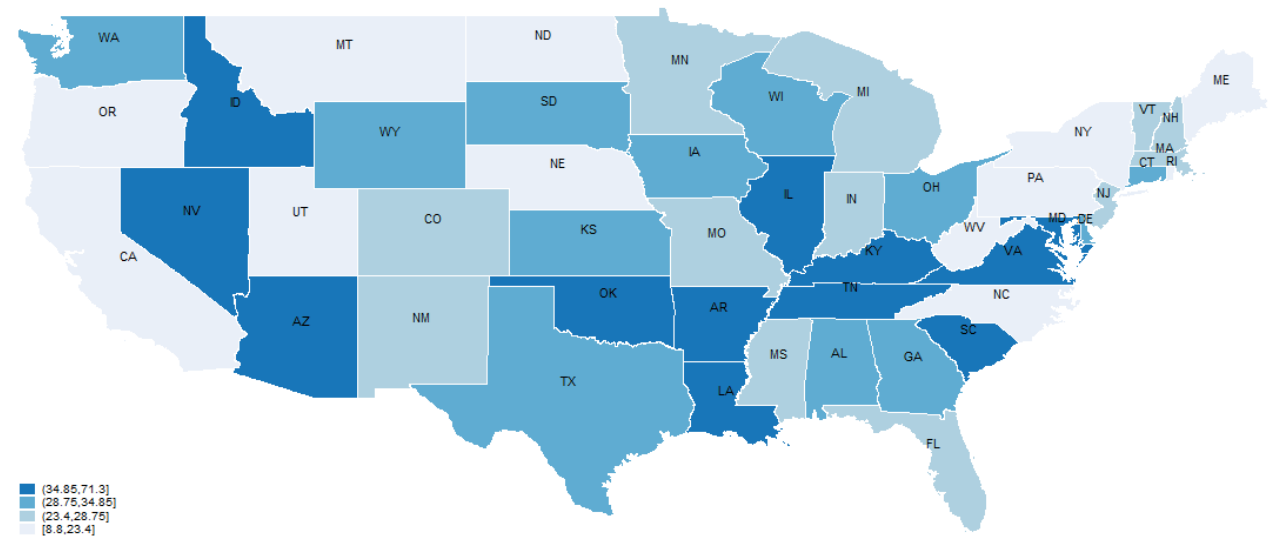

Note: Calculations of the percentage changes have been conducted by the authors. The decline in marriage rates increases with darkness.

Source: CDC/NCHS, National Vital Statistics System.

The diminution of marriage is not an isolated phenomenon but instead has taken place alongside an increase in cohabitation (/shizuka 2018), economic improvements for women (Becker 1991; Cherlin 1992), access to contraception (McLanahan 2004; Stevenson/Wolfers 2007), and lower levels of marriageability among men (Bridges/ Boyd 2016). The percentage of men between 18 and 24 years of age living with a spouse in the US reduced from 31.2 in 1967 to 5.1 in 2016 (Fig. 2). The percentage for women is 46.3 and 9.1, respectively. Conversely, the percentage of young adults living in partnerships has increased (Fig. 2). The latter reveals a trend towards delaying marriage (Fig. 3).

The postponement in younger ages is also in line with Willoughby et al. (2015), who argue that marriage still remains important for young adults; more important than careers and leisure activities. Indeed, we see that the decline is less prominent as we move to individuals who are over 50 years old (see Fig. 3; dashed line and right $y$-axis). Hence, one could infer that the drop we observe at younger ages may reflect economic considerations. Instead, the relatively smaller decline for individuals over 50 might be a result of factors other than those that are economic in nature (ethical, 
Fig. 2: $\quad$ Percentage of married and cohabiting young adults aged 18-24

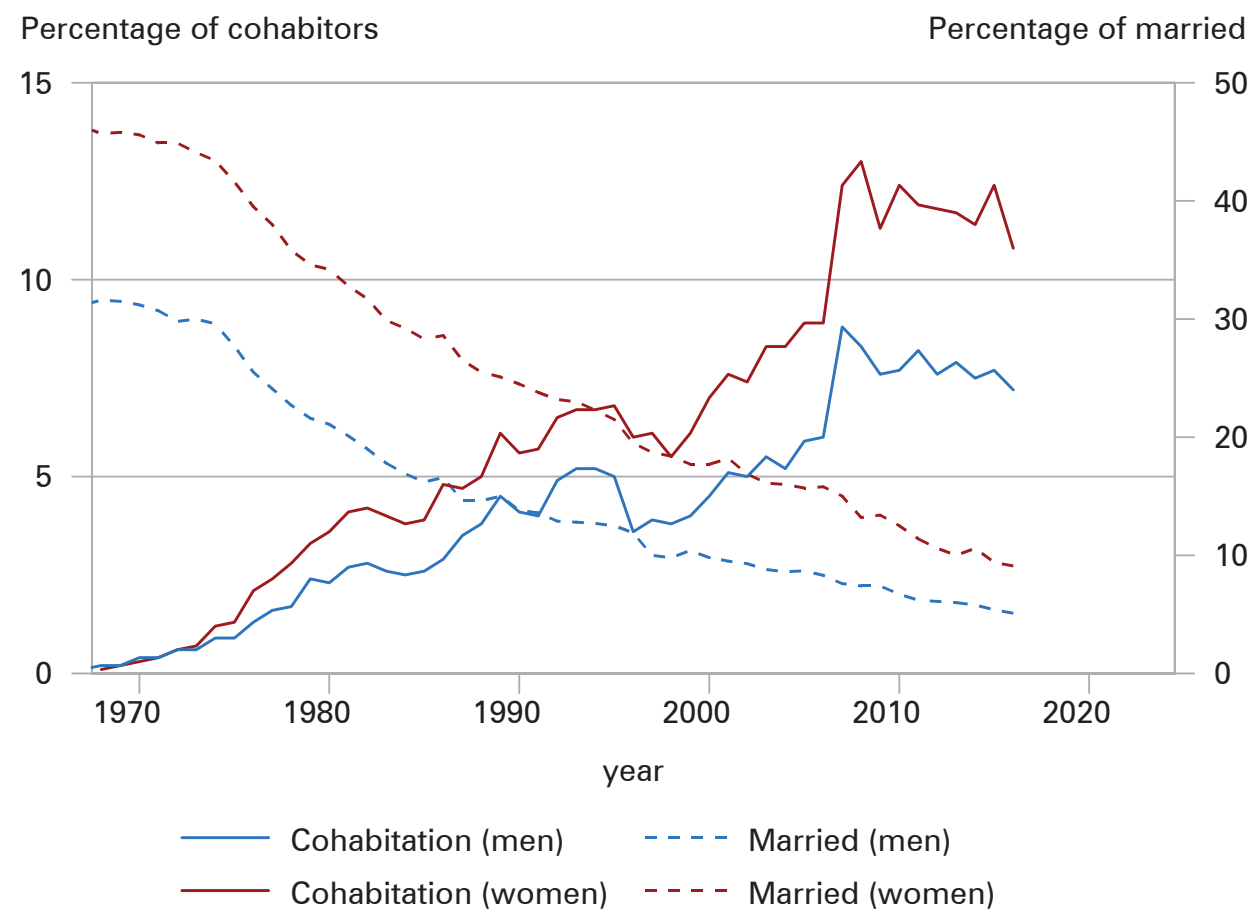

Source: US Census Bureau, Current Population Survey, Annual Social and Economic Supplement.

political, religious, etc.). This evidence is consistent with Easterlin's hypothesis as we explain in the following section.

However, Easterlin's hypothesis has not always been applied in the literature within its original context. ${ }^{1}$ Another purpose of this study is to fill this gap. We contribute to this strand of the literature by investigating the question: why do young adults retreat from marriage in the US? To answer, we rely on the Easterlin relative income hypothesis, the original setup of which we tried to replicate as closely as possible. We show that the ratio computed by earnings and material aspirations ${ }^{2}$ is an important factor that is positively correlated to marriage. Thus, the reduction of relative income over the years may offer an explanation for young adults' retreat from marriage. The latter may also be a solution to the "marriage paradox".

1 For a criticism on the relativity measures that have been used to test Easterlin's hypothesis (not solely with respect to marriage), see Macunovich (1997, 1998a/b).

2 Hereinafter we refer to material aspirations simply as aspirations. 
Fig. 3: Median age at first marriage for men and women, and the percentage of married individuals (white non-Hispanics) aged over 50 years old

Age at first marriage

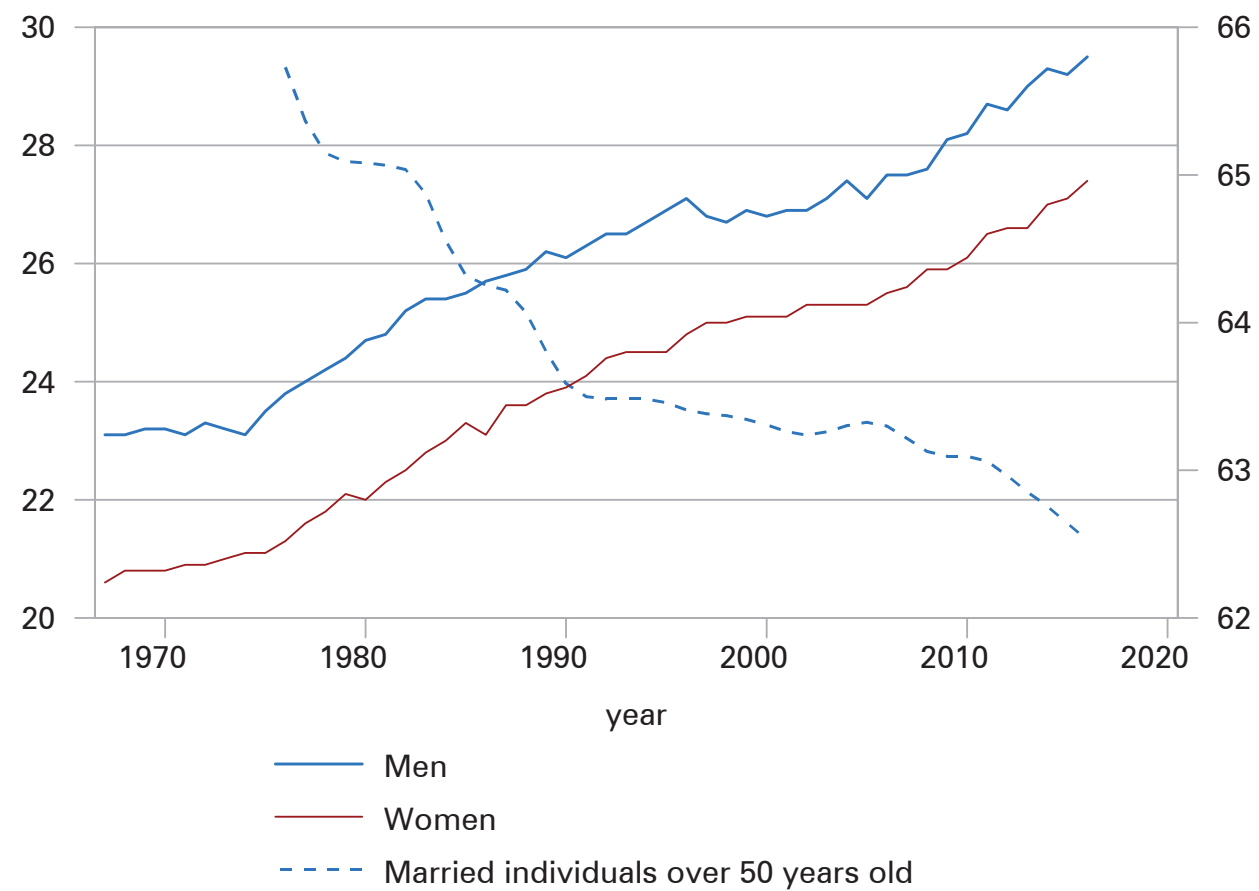

Source: For the age at first marriage: US Census Bureau, Current Population Survey, March and Annual Social and Economic Supplements. For married individuals above 50: Own calculations employing data extracted from the IPUMS-CPS.

\section{$2 \quad$ Literature review}

The existing literature suggests a number of factors that contributed to the decline in marriage rates in the US over recent decades. Social scientists focus mostly on the importance of gender roles in marriage stability (Parsons 1949; Pessin 2018). Becker (1991), on the other hand, examines gender roles following an economic approach. Inspired by the international trade theory, Becker argues that men and women will choose to get married only if the gains of marriage are greater than remaining single. This theory sees individuals as trade partners whose gains from marriage are maximised when each one specialises in a specific domain: men being part of the labour market and women undertaking household work. Thus, as women have been improving their position in society through labour force participation, educational attainment and higher earnings, benefits from marriage have been weakening. As a result, marriage rates have decreased.

Becker's contention had a great appeal in economics and many attributed the retreat from marriage to women's emancipation (Ermisch 1981; McLanahan/Casper 
1995; Sass/er/Schoen 1999; Sweeney 2002). However, Oppenheimer $(1988,1997)$ questions the power of Becker's trade theory on marriage and provides evidence on the deterioration of young men's labour market position. Oppenheimer also notes that most aggregate cross-sectional studies find that female empowerment has a negative effect on marriage whilst individual-level longitudinal studies find the opposite. Consequently, this effect is rather mixed and depends on the approach adopted.

Another major theory on marriage relates to ideological issues. According to Van De Kaa (1987), shifts in ethical, political, and religious beliefs are responsible in large part for the decline in marriage. Other explanations consider the effect of the "marriage squeeze" theory (sex ratio). The latter implies that the existence of a greater number of women relative to men, for instance, would worsen women's chances of finding a partner. Angrist (2002) tests the squeeze theory on marriage patterns in second generation immigrants and finds a positive sex ratio effect for women. More recently, Bronson/Mazzocco (2018) suggest that changes in cohort size over time and across states explain about half of the variation in US marriage rates since the early twentieth century. Finally, technological changes on birth control such as pill contraceptives (Goldin/Katz 2002) and abortion availability (Akerlof et al. 1996) affect the desire to marry.

Easterlin (1987) claims that young adults' decisions regarding a number of issues, such as marriage and fertility, are based on their relative affluence. Aspirations shape a consumption threshold for each generation (macro perspective) or individual (micro perspective) and function as an inward implicit premise for various demographic events. The formation of the consumption threshold stems from childhood (Easterlin 1987). Easterlin formulated his theory to interpret the postWorld War II baby boom and bust in the US. His theory posits cyclical changes in demographic and social behaviour due to the fluctuations in birth rates. Thus, a large cohort will produce a small cohort due to the unfavourable labour market conditions that it encounters, while a small cohort will produce a large one. Easterlin developed two measures to test his hypothesis: the relative cohort size and the relative income (RY hereinafter). The two concepts - despite their linkage - have been proved to be different. ${ }^{3} \mathrm{~A}$ discrepancy between the two measures had already been observed since 1973 (Macunovich 1998a). Therefore, Easterlin's theory could be split into two perspectives. The first concerns the relative cohort size, and the second concerns the RY. ${ }^{4}$ This paper focuses on the second perspective.

Easterlin discusses the role of aspirations on the decision-making process of young adults. The family income of their parents during childhood years acts as a proxy for young adults' aspirations (Easterlin 1966). Easterlin claims that there is a positive correlation; the higher the family income in childhood, the higher the

3 For a discussion on the opposite direction of relative cohort size movements than that proposed by Easterlin, see Lutz et al. (2006).

4 RY refers to the wage of young men relative to the family income enjoyed in the parental house. A more thorough description is provided in Section 4. 
aspirations that are formed and transmitted to young adulthood. ${ }^{5}$ However, the main problem with the construction of RY is the formation of the denominator which represents aspirations (Macunovich 1997). Aspirations are formed within the household, but they are also shaped by the influence of peers, neighbourhood, school, television, and other sources (Richins 2017). Hence, it might be crucial to take into account the (average) income of all families in a specific area (e.g. states in our case). With respect to marriage, the conclusion of the Easterlin hypothesis could be presented in a nutshell as follows: young adults whose incomes are high enough relative to their desired consumption threshold ${ }^{6}$ will feel freer to wed. Otherwise, they will choose to postpone - until they reach this threshold - or even forgo marriage.

The RY hypothesis has been widely tested in the literature on fertility but it has received less attention with respect to marriage (Pampel/Peters 1995: 180). Macunovich (2011) contends that there are only two studies in the relevant literature which have tested directly the relationship between RY and marriage: MacDonald/ Rindfuss (1981) and Macunovich (2002). "There have been two studies that have tested this relationship between relative income and marriage directly - that is, using older family income: MacDonald and Rindfuss (1981) and Macunovich (2002), with the first finding no support for the theory, and the second finding strong support. Other studies have looked at the effect indirectly - using parental education and/or occupation as proxies for income." (Macunovich 2011: 18).

MacDonald/Rindfuss (1981) investigated a sample of men who graduated from Wisconsin high schools in 1957 and found no support for the relative income hypothesis. Their conclusion suggests that family formation is affected only by the absolute income. Schapiro (1988) finds his measure of RY to predict divorce but not marriage rates. The third paper that tests the RY hypothesis for marriage in a manner that is closer to the original concept of RY is that of Macunovich (2011). Macunovich used the parental family income of men and women currently married who were $0-5,6-10$, and $11-15$ years out of school. Findings revealed a negative effect of family income on marriage. However, the use of the family income without considering the wage (income) variation is not in line with Easterlin's relative income hypothesis. Aspirations per se cannot capture adequately the latter. Macunovich was no doubt aware of this. Nevertheless, she tried to conduct a more micro-oriented approach as she explained: "Macunovich (2002) found support for the hypothesis, however, using parental income at a more aggregated level." (Macunovich 2011: 3; italics come from us).

Macunovich indicates that "[...] there has been a wide diversity of measures which have been developed empirically and tested in the name of the 'Easterlin Hypothesis' [...]". Easterlin responded to this comment as follows: "I think it's just a

5 The late work of Easterlin on the economics of happiness recognised that young adults may have the same level of aspirations regardless of their family background (Easterlin 2001).

6 For a clarification of the concept of childhood family income and its relation to consumption threshold, see Macunovich (1998a: 102). 
lack of thought. The simplest thing is just mechanically to try various measures rather than reflect on whether the measures capture the conceptual idea." Macunovich insisted: "Some studies, for example, have compared the current average income of all males, to lagged values of that same variable - demonstrating a serious misunderstanding of the concept. Do you find this frustrating?" Easterlin too: "Yes, I do. I've tried to stress that it is important to look at the particular circumstances of young people, and measures based on data for all adults fail to embody this essential notion." (Macunovich 1997: 122).

In the same spirit, Macunovich (1998a: 55) points out: "[...] an examination of the studies which provide least support might lead some to question whether they actually address the Easterlin hypothesis as he formulated it - but this could be said for several of the supportive studies as well! Sometimes because of data limitations, sometimes because of widely varying interpretations of the hypothesis, researchers have conducted studies which seem to bear little resemblance to the hypothesis." Bearing in mind the above comments (and others), we tried to replicate the Easterlin RY hypothesis as closely as possible when conducting our analysis. In other words, we focus on young adults and we take the lagged age-specific family income that represents their parental generation.

Among studies dealing with Easterlin's RY hypothesis on marriage, those by MacDonald/Rindfuss (1981) and Macunovich (2002) appear to be more focused on Easterlin's conceptual idea. However, their findings are contradictory: one study provides evidence against the hypothesis (MacDonald/Rindfuss 1981), the other in favour of the hypothesis (Macunovich 2002). This paper contributes to the relevant literature by exploiting recent data that spans up to 2016. We also employ dynamic panel data methods and Granger non-causality tests that had not been considered before in this framework. We also differentiate from the previous literature by incorporating the female labour force participation into the marriage model as a measure of women's emancipation (Upadhyay et al. 2014). Finally, we compare relative income to absolute income. That comparison had also been conducted by MacDonald/Rindfuss (1981), albeit without controlling for the female dimension.

\section{$3 \quad$ Methodology}

\subsection{Model specification}

We follow a dynamic approach based on the FE estimator with a lagged dependent variable. The latter may cause what Nickell (1981) has called dynamic panel bias. That could be corrected by using the Arellano-Bond estimator (difference GMM) which removes fixed effects by taking first differences (Arellano/Bond 1991; Roodman 2009). However, the moderate value of $T(=35)$ is not small enough to avoid overfitting of the variables to be instrumented, nor large enough to argue that the dynamic panel bias is insignificant. Thus, we apply the bias-corrected dynamic panel estimator (Bruno 2005a/b). 
We consider RY, female labour force participation, and the unemployment rate among young men as endogenous variables since reverse causality might occur if men decide to postpone or forgo marriage in order to increase their education (Nie/sen et al. 2009), or to fulfil their aspirations before marriage. By increasing their education, the corresponding unemployment might also be affected. ${ }^{7}$ Thus, the decline in marriage could impact on both RY and unemployment rates of young men. The same may also apply to women's labour force participation. Women decide to increase their participation in the labour market either because men postpone marriage, or due to their own decision to continue their education and consequently earn higher wages. Hence, two lags have been imposed on the independent variables. The equation to be estimated is as follows:

$$
\text { marriage }_{i, t}=b_{0}+b_{1} \text { marriage }_{i, t-1}+b_{2} R Y_{i, t-2}+\sum_{j=3}^{4} b_{j} X_{i, t-2}^{\prime}+\sum_{k=1}^{4} b_{5 k} \text { dummy }_{k}+\mu_{i}+u_{i, t}
$$

where subscripts $i$ and $t$ denote state and year, respectively; marriage $e_{i, t}$ is the marriage rate, $R Y_{i, t-2}$ is the relative income of young men, $X_{i, t-2}^{\prime}$ denotes a vector of control variables, dummy ${ }_{k}$ represents the decade dummy that takes value 1 for the decade of reference $(k)$ or otherwise takes value $0, \mu_{i}$ is the fixed effect term and $u_{i, t}$ stands for the stochastic error term. To compare ${ }^{8}$ the effect of the relative income to the absolute income (AY hereinafter) on marriage, we re-run equation (1) by replacing the former with the latter. ${ }^{9}$

The panel is unbalanced. The FE estimator is still consistent under unbalanced panels as long as missing observations are random (Wooldridge 2002). Plausible estimation problems might arise from the correlation between and within states. For this purpose, we perform tests for cross-sectional dependence (CSD), serial correlation (first order), and stationarity. The latter is largely ensured by the fact that variables are bounded (Farmer 2015) through the normalisation process. However, we test stationarity by employing the Pesaran (2007) unit root test for panel data. ${ }^{10}$ Normalisation also induces a rescaling which allows us to compare the contribution between the relative and absolute income.

Cross-sectional dependence has been examined with the Pesaran (2015) test. The null hypothesis of cross-sectional independence was rejected (Appendix D, Table D1). Lastly, we check for the presence of first order autocorrelation using

7 Unemployment is mostly affected by macroeconomic factors and can be considered as exogenous for marriage. Thus, we have also repeated the analysis without imposing lags on unemployment. Results do not significantly deviate from those presented in Section 5.1 (available upon request).

8 Variables have been normalised (range between 0 and 1) so that their relative contribution on marriage is comparable.

9 In this we follow Macunovich (1998a: 72).

10 The null hypothesis of non-stationarity has been rejected in all cases. Results are available upon request. For bounded processes unit root tests, see Carrion-i-Silvestre/Gadea (2013) and Cavaliere/Xu (2014). 
the Wursten (2018) test. The presence of serial correlation would imply the loss of information hidden in the error term if we were only to consider a static model. ${ }^{11}$ Results displayed in Appendix (Table D2) indicate the presence of first order autocorrelation in all cases.

\subsection{Granger non-causality test}

We apply the Granger non-causality procedure proposed by Dumitrescu/Hurlin (2012) to test for any causal effects of relative income on marriage. Dumitrescu and Hurlin's method has the advantage of controlling for heterogeneous panel data models. The latter allows for weaker assumptions regarding the homogeneity of the cross-sectional units. It also applies a block bootstrap procedure to obtain the critical values (instead of the asymptotic ones) with the aim of correcting for crosssectional dependence. Moreover, the number of lags can be chosen based on one of the selection criteria (AIC, BIC, HQIC), see Lopez/Weber (2017: 983).

The specification is as follows:

$$
\text { marriage }_{i, t}=a_{i}+\sum_{k=1}^{K} \beta_{i}^{(k)} \text { marriage }_{i, t-k}+\sum_{k=1}^{K} \gamma_{i}^{(k)} R Y_{i, t-k}+\varepsilon_{i, t}
$$

where $k$ is the number of lags which are identical for all cross-sectional units of the panel; the coefficients $\gamma_{i}^{(k)}$ and $\beta_{i}^{(k)}$ denote the autoregressive parameter and the regression coefficient slopes, respectively. Both are allowed to differ across groups. $\alpha_{i}$ is the fixed individual effect and $\varepsilon_{i, t}$ indicates the residuals. The null hypothesis (no causality) is defined as:

$$
H_{o}: \gamma_{i 1}=\ldots=\gamma_{i k}=0 \quad \forall i=1, \ldots, N
$$

and the alternative hypothesis (causality) as:

$$
\begin{array}{cc}
H_{1}: \gamma_{i 1}=\ldots=\gamma_{i k}=0 & \forall i=1, \ldots, N_{1} \\
\gamma_{i 1} \neq 0 \text { or } \ldots \text { or } \gamma_{i k} \neq 0 & \forall i=N_{1}+1, \ldots, N
\end{array}
$$

where $N_{1} \in[0, N-1]$ is unknown.

It should be noted that rejecting the null hypothesis does not exclude the possibility of no causality for some states. This is an issue that should be further investigated in future work. On the other hand, not rejecting the null hypothesis would mean that there is no Granger causality for any state.

11 The static model reveals that the coefficient of the $R Y$ is positive and statistically significant at the 1 percent level of significance in all cases examined. Results are available upon request. 
This methodology is not suitable for unbalanced panels (Lopez/Weber 2017: 973), which is why we proceed with the balanced version of our dataset. The latter caused a significant drop in observations (from 1724 to 828). The Lopez/Weber (2017) approach has been applied in this case. In the regression analysis that follows, lags have been selected on the basis of the Bayesian criterion. Finally, the variables considered for the causality test have to be stationary (Lopez/Weber 2017: 977).

\section{Data description}

Data were drawn from the IPUMS-CPS and begin in 1962. We restricted the time dimension due to the lack of relevant variables needed for the development of RY. Consequently, the analysis spans the period between 1976 (1981 taking into account the 5-year lags of the relative income) and 2016. All states have been included apart from Alaska, District of Columbia, and Hawaii. The analysis has been also restricted to white non-Hispanics due to their high level of representativeness in the IPUMSCPS database. For instance, the main file of IPUMS-CPS that was downloaded contains $8,677,348$ observations, of which 7,280,335 refer to whites and $6,674,636$ (out of $8,677,348$ ) to white non-Hispanics. In keeping with Macunovich (2012), we retain only civilians. All variables have been developed (aggregated) by year, state, race, and age.

The numerator of the developed RY consists of the wages for men between the ages of 15 and 24, who are single (never married), worked full time, and completed 52 weeks of employment during the previous year (full-time, year-round workers). Wages refer to the total pre-tax wage and salary income for the previous calendar year. It is crucial to include only those persons who have completed 52 weeks, otherwise annual wages earned by individuals would present considerable heterogeneity and their RYs would not be comparable. For instance, a young man with a stable job (52 weeks) and full-time employment status could have greater chances of getting married. A young man who has worked less than 52 weeks per year, and/or who has part-time status, may delay marriage even if his aspirations are low compared to his full-time, year-round worker peers. In this case, the role of aspirations is relegated beforehand. Thus, a full-time, year-round worker could be the basis for testing the RY effect on marriage.

The aim of including only full-time, year-round workers is also to exclude the possibility of educational-driven impacts on marriage, i.e. young adults retreating from marriage because of their attendance in higher education. Despite that, we also test for the latter, showing results for young men aged 15-24 who attained a level of education that was equal to or more than high school but less than a bachelor's degree (Appendix C). The latter educational category has been considered because this is the most representative cluster for the age group under examination (total: 43,356 individuals; less than high school: 14,726 individuals; equal to or more than high school but less than a bachelor's degree: 25,820 individuals; equal to or more than a bachelor's degree: 2,810 individuals). 
We have also restricted the sample to those who are native-born (we used the variable $b p /$ - birth place - which unfortunately starts in 1994) in order to increase the odds of capturing their aspirations in childhood. Next, we replaced the top-coded wages with the swap values for the years 1976-2010 and dropped the top-coded wages for the rest of the period (for more details see https://cps.ipums.org/cps/ topcodes_tables.shtml). We dropped individuals from the analysis if their calculated wage per hour was less than $\$ 2.50$ or more than $\$ 250$ in 2008 dollars (B/au/Kahn 2007). The wage has been estimated as the median of all individuals by year, state, race, and age. We considered the median calculation instead of the mean because the wage distribution was mostly skewed towards the right side.

In the denominator, we set the family income which has been lagged by 5 years in order to proxy the aspirations of young males. The choice of 5-year lags (instead of 3-year or 10-year lags for instance) relates to Easterlin's initial work (see Easterlin 1966; Macunovich 1998a), and data limitations. Thus, we stay closer to Easterlin's original approach and have more data points for the analysis. For instance, if we impose a lag of 3 years, the maximum age of the individuals considered in the analysis would be 24 years old, which would mean that the aspirations relate to when they were 21 years old (high enough). On the other hand, a lag choice of 10 years would catch aspirations plausibly better than 5 , but with the cost of fewer observations. The use of family income (total family income) instead of solely the male's income, is warranted by the increased pace of women's contribution to family income and therefore to child's aspirations (Macunovich 2011). Through the selection of the specific age group of young adults (15-24) and the assumed mean age at birth (30), we conclude that their parents' age will range between 45 and $54(15-24,+30)$ where the parental family income has been calculated and lagged. We adopt the age of 30 since we aim to capture aspirations for all the possible birth orders of young adults. ${ }^{12}$ For the mean age at birth of a male in the US, see Khandwala et al. (2017); for the mean age at birth of a female, see Mathews/Hamilton (2002, 2016).

Unlike the numerator of RY, the denominator has not been restricted to nativeborn citizens. If the individuals are immigrants, or of a lower socioeconomic status, they contribute equally to the median family income of each state; in turn, this is assumed to form material aspirations. This is because psychologists have for a long time indicated the tendency of individuals to make social comparisons (Festinger 1954). The latter could be either upward or downward (Buunk/Gibbons 2007). Accordingly, we consider all the directions in the denominator with no exclusions. In the denominator, we only retained those who reported having at least one child and were the householder (coded as "Head"). Again, as in the numerator, we used the median instead of the mean calculation for the reason already mentioned. On the marriage rate estimation, we follow Sweeney (2002) - both male and female marriage rates - as well as Macunovich (2011), who distinguishes between the two.

12 Obviously, a higher birth order relates to an older parental age at birth as well. Adopting the mean age at first birth would probably be misleading. 
Fig. 4: $\quad$ Relative income and marriage rate of young men between 15 and 24 years old for the US

Relative income 15-24

Marriage rate 15-24

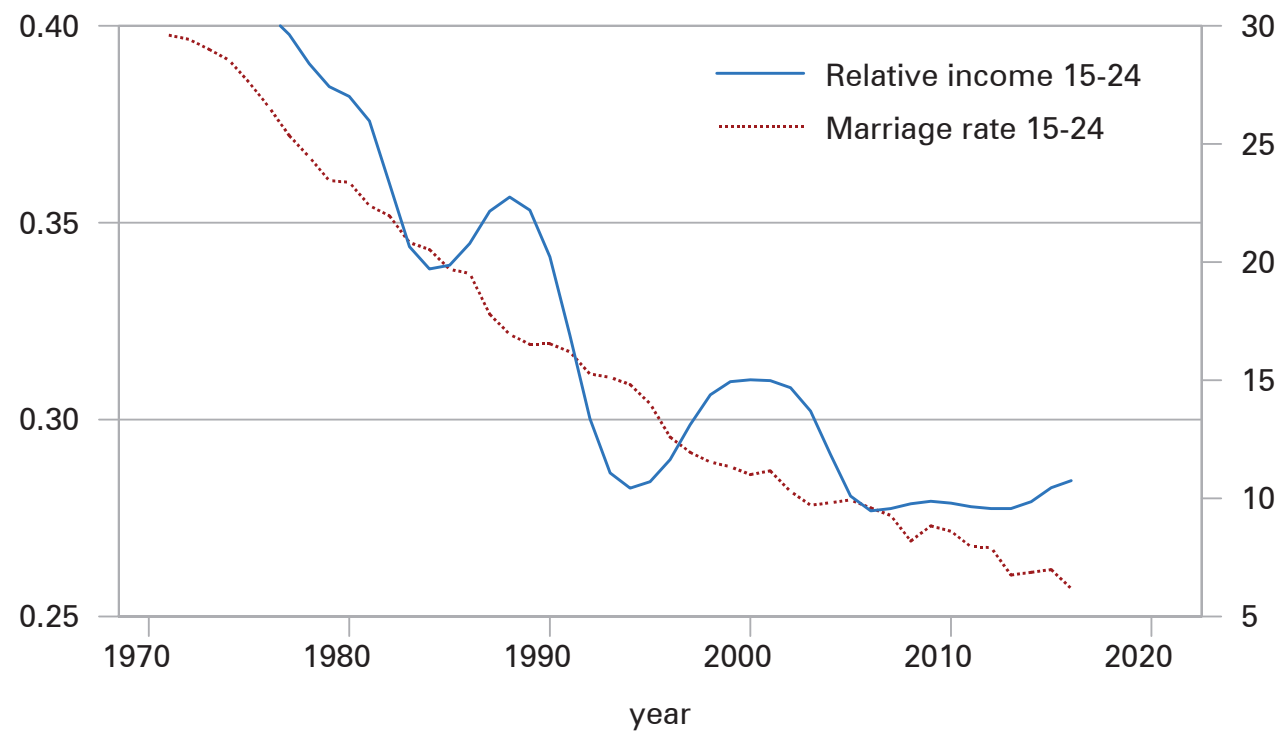

Note: Relative income has been smoothed. Marriage rate refers to young men (age 15-24). Source: Own calculations employing data extracted from the IPUMS-CPS.

Figure 4 depicts the evolution of RY and marriage for white non-Hispanic men aged 15-24 in the US. Both have been declining. For RY, we observe a decline until the mid-1990s followed by an increase and then stagnation around 2000. After a short period in which it decreased, RY has been relatively steady from 2006 onwards.

Other factors may also affect the decision to marry. We consider two additional variables: female labour force participation, which also serves as a measure of women's empowerment (Upadhyay et al. 2014); and the unemployment rate of young men (González-Val/Marcén 2018). All variables were smoothed (running medians) and normalised (sum to unity) in order to address scale disparity. Decade dummies have been included; one dummy for each one of the four decades (plus the constant). Dummies aim to capture time-varying effects which could affect marriage such as the level of inequality, cohabitation, ${ }^{13}$ sex ratio (marriage "squeeze"), contraception, divorce rates, etc. Table 1 presents the descriptive statistics. Table 2 provides the calculated formulas for the variables employed.

Finally, it is important to underscore some of the advantages and disadvantages of employing aggregate instead of micro-data on the RY hypothesis.

13 We can capture cohabitation indirectly by the use of dummies. IPUMS-CPS provides data on cohabiting partners from 2007 onwards. 
Tab. 1: Descriptive statistics

\begin{tabular}{lrrrrr}
\hline Variable & Obs. & \multicolumn{1}{c}{ Mean } & Std. Dev. & Min. & Max. \\
\hline Marriage rate (b) & 1,724 & 13.452 & 7.374 & 0.754 & 38.462 \\
Marriage rate (f) & 1,724 & 15.728 & 8.522 & 0.714 & 43.421 \\
Marriage rate (m) & 1,724 & 8.944 & 5.447 & 0.465 & 28.049 \\
Relative income & 1,724 & 0.308 & 0.072 & 0.108 & 0.915 \\
Absolute income & 1,724 & 25,010 & 4827.085 & 10,000 & 47,297 \\
Female labour force & & & & & \\
participation & 1,724 & 56.114 & 8.829 & 28.283 & 82.353 \\
Unemployment rate (m) & 1,724 & 13.503 & 5.812 & 1.754 & 38.889 \\
\hline Relative income & 1,545 & 0.309 & 0.087 & 0.126 & 0.950 \\
Absolute income $^{*}$ & 1,545 & 26,846 & 5,952 & 8,000 & 68,883 \\
\hline
\end{tabular}

Note: $\mathrm{f}$ : female, $\mathrm{m}$ : male, b: both male and female. ${ }^{*}$ For young men of equal to or more than high school but less than bachelor's degree.

Source: Own calculations employing data extracted from the IPUMS-CPS.

On the one hand, aggregate analysis arising from micro-data has been criticised by Robinson (1950) who referred to the "ecological fallacy". The latter points out the incorrect assumptions made about an individual, based on the characteristics of the group to which s/he belongs. Moreover, Simpson (1951) supports the view of a reversal in the sign between the aggregate and the individual-level analysis (see also Oppenheimer 1997).

On the other hand, tests at the micro-level have treated aspirations as being only a function of parental income by using either gross proxies for the RY measure such as "How well-off are you?" or, to a lesser degree, by employing the incomes of their parents. Such approaches neglect the influence that peers, neighbourhood, or other social phenomena also have on individual aspirations. Conducting the analysis at the aggregate level, we remedy this drawback.

\section{$5 \quad$ Estimation results}

\subsection{Regression results}

Table 3 presents the results obtained by employing the panel dynamic FE estimator. The lagged value of the dependent variable is always statistically significant at the 1 percent level of significance. Coefficients on both incomes are positive but 
Tab. 2: Calculation formulas for the variables employed

\begin{tabular}{|c|c|}
\hline Variable & Calculation $^{a}$ \\
\hline $\begin{array}{l}\text { Marriage rate of young adults } \\
\text { (men and/or women) }\end{array}$ & $\sum_{\mathrm{i}=1}^{48} \sum_{\mathrm{t}=1981}^{2016} \frac{\text { Number of } \text { married }_{\mathrm{i}, \mathrm{t}}}{\text { Total population }} \mathrm{i,t}$. 100 \\
\hline
\end{tabular}

Relative income of young men

$$
\sum_{\mathrm{i}=1}^{48} \sum_{\mathrm{t}=1981}^{2016} \frac{\text { Male wage }_{\mathrm{i}, \mathrm{t}}}{\text { Family income }_{\mathrm{i}, \mathrm{t}-5}}
$$

Absolute income of young men

$$
\sum_{\mathrm{i}=1}^{48} \sum_{\mathrm{t}=1981}^{2016} \text { Male wage }_{\mathrm{i}, \mathrm{t}}
$$

Labour force participation of young women

$$
\sum_{\mathrm{i}=1}^{48} \sum_{\mathrm{t}=1981}^{2016} \frac{\text { Female labour force }_{\mathrm{i}, \mathrm{t}}}{\text { Total female population }_{\mathrm{i}, \mathrm{t}}} * 100
$$

Unemployment rate of young

$$
\sum_{i=1}^{48} \sum_{t=1981}^{2016} \frac{\text { Number of unempl. } \text { men }_{i, t}}{\text { Lab. force partic. of } \text { men }_{i, t}} * 100
$$

a $i$ refers to state and to year. In all cases, we adjust for white non-Hispanics in the age group 15-24.

Source: Own calculations employing data extracted from the IPUMS-CPS.

significant only for the RY. ${ }^{14}$ In all cases, the RY exerts a greater impact on marriage than the AY. The latter implies that young men tend to decide on a comparative basis as Easterlin suggests. Beyond other criteria, it seems that childhood circumstances indeed compete with the circumstances in young adulthood during the decision process. This inference lends support to the findings of Willoughby et al. (2015) as already mentioned. We also observe that the coefficients of RY and AY are higher for the "Male" category. On the covariates, both young men unemployment and young women labour force participation are negatively related to marriage. Their effect is greater than that of RY and AY and always highly significant ( $p$-value $<0.01)$. Hence, marriage decreases as female labour participation grows, which is consistent with female emancipation theories (Guvenen/Rendall 2015).

14 An anonymous referee noted that the Easterlin effect of relative income might be expected on the opposite direction (negative correlation with marriage) because the household equivalent income is augmented by marriage, whereas it is reduced by fertility. We found no evidence for the latter. 
Tab. 3: $\quad$ Panel dynamic FE estimator

\begin{tabular}{|c|c|c|c|c|c|c|}
\hline & $\begin{array}{c}\text { (1) } \\
\text { Both }\end{array}$ & $\begin{array}{c}(2) \\
\text { Male }\end{array}$ & $\begin{array}{c}\text { (3) } \\
\text { Female }\end{array}$ & $\begin{array}{c}\text { (4) } \\
\text { Both }\end{array}$ & $\begin{array}{c}(5) \\
\text { Male }\end{array}$ & $\begin{array}{c}(6) \\
\text { Female }\end{array}$ \\
\hline Marriage $_{t-1}$ & $\begin{array}{l}0.977^{* * *} \\
(0.011)\end{array}$ & $\begin{array}{l}0.970^{* * *} \\
(0.009)\end{array}$ & $\begin{array}{l}0.970^{* * *} \\
(0.013)\end{array}$ & $\begin{array}{l}0.981 * * * \\
(0.012)\end{array}$ & $\begin{array}{l}0.973^{* * *} \\
(0.010)\end{array}$ & $\begin{array}{l}0.974^{* * *} \\
(0.013)\end{array}$ \\
\hline$R Y_{t-2}$ & $\begin{array}{l}0.029 * \\
(0.014)\end{array}$ & $\begin{array}{l}0.033^{* *} \\
(0.016)\end{array}$ & $\begin{array}{l}0.028 * \\
(0.014)\end{array}$ & & & \\
\hline$A Y_{t-2}$ & & & & $\begin{array}{c}0.016 \\
(0.013)\end{array}$ & $\begin{array}{c}0.019 \\
(0.014)\end{array}$ & $\begin{array}{c}0.015 \\
(0.013)\end{array}$ \\
\hline FLFP $_{\mathrm{t}-2}$ & $\begin{array}{l}-0.077 * * * \\
(0.014)\end{array}$ & $\begin{array}{l}-0.081 * * * \\
(0.012)\end{array}$ & $\begin{array}{l}-0.073^{* * *} \\
(0.015)\end{array}$ & $\begin{array}{l}-0.073^{* * *} \\
(0.014)\end{array}$ & $\begin{array}{l}-0.076^{* * *} \\
(0.012)\end{array}$ & $\begin{array}{l}-0.070^{* * *} \\
(0.015)\end{array}$ \\
\hline Unemployment $\mathrm{t}_{\mathrm{t}-2}$ & $\begin{array}{l}-0.042^{* * *} \\
(0.011)\end{array}$ & $\begin{array}{l}-0.042^{* * *} \\
(0.012)\end{array}$ & $\begin{array}{l}-0.039 * * * \\
(0.011)\end{array}$ & $\begin{array}{l}-0.044^{* * *} \\
(0.011)\end{array}$ & $\begin{array}{l}-0.045^{* * *} \\
(0.012)\end{array}$ & $\begin{array}{l}-0.041^{* * *} \\
(0.011)\end{array}$ \\
\hline Constant & $\begin{array}{l}0.060^{* * *} \\
(0.015)\end{array}$ & $\begin{array}{l}0.065^{* * *} \\
(0.016)\end{array}$ & $\begin{array}{l}0.064^{* * *} \\
(0.016)\end{array}$ & $\begin{array}{l}0.062^{* * *} \\
(0.014)\end{array}$ & $\begin{array}{l}0.068^{* * *} \\
(0.015)\end{array}$ & $\begin{array}{l}0.067^{* * *} \\
(0.015)\end{array}$ \\
\hline $\begin{array}{l}\text { R-squared } \\
\text { Number of }\end{array}$ & 0.966 & 0.955 & 0.965 & 0.965 & 0.955 & 0.965 \\
\hline Observations & 1,574 & 1,574 & 1,574 & 1,574 & 1,574 & 1,574 \\
\hline
\end{tabular}

Note: Dependent variable: Marriage rate. ${ }^{* * *} p$-value $<0.01,{ }^{* *} p$-value $<0.05,{ }^{*} p$-value $<0.1$. FLFP stands for female labour force participation. Decade dummies have been included.

Source: Own calculations employing data extracted from the IPUMS-CPS.

Table 4 aims to control for endogeneity by employing the bias-corrected FE estimator. We see that both absolute and relative income are positive and statistically significant. As in Table 3, RY has a greater impact on marriage compared with AY. The covariates are again negatively related to marriage. Female labour participation has the most profound effect. The results presented in this section indicate that $\mathrm{RY}$ is an important predictor for marriage, thereby corroborating the Easterlin hypothesis. Furthermore, in all of the methods employed, the indication is that RY has been more significant in both statistical and size aspects relative to the AY. Young women's empowerment leads to a decline in marriage, according to findings on female labour force participation. Lastly, unemployment among young men emerges as a deterrent with regard to marriage. The latter shows that uncertainty is a crucial determinant on decisions regarding early marriage.

\subsection{Granger non-causality tests}

This section employs the Dumitrescu/Hurlin (2012) Granger non-causality test as formulated by Lopez/Weber (2017). We test for both directions of causality: from $\mathrm{RY}$ to marriage and from marriage to RY. Table 5 refers to the former. The $p$-values indicate statistical significance at the 1 percent level except for male marriage which 
Tab. 4: Bias-corrected FE estimator

\begin{tabular}{|c|c|c|c|c|c|c|}
\hline & $\begin{array}{c}\text { (1) } \\
\text { Both }\end{array}$ & $\begin{array}{c}(2) \\
\text { Male }\end{array}$ & $\begin{array}{c}(3) \\
\text { Female }\end{array}$ & $\begin{array}{l}\text { (4) } \\
\text { Both }\end{array}$ & $\begin{array}{c}\text { (5) } \\
\text { Male }\end{array}$ & $\begin{array}{c}(6) \\
\text { Female }\end{array}$ \\
\hline Marriage $_{t-1}$ & $\begin{array}{l}0.977^{* * *} \\
(0.012)\end{array}$ & $\begin{array}{l}0.970 * * * \\
(0.011)\end{array}$ & $\begin{array}{l}0.970 * * * \\
(0.012)\end{array}$ & $\begin{array}{l}0.980 * * * \\
(0.012)\end{array}$ & $\begin{array}{l}0.973^{* * *} \\
(0.011)\end{array}$ & $\begin{array}{l}0.974 * * * \\
(0.012)\end{array}$ \\
\hline$R Y_{t-2}$ & $\begin{array}{l}0.029 * * * \\
(0.009)\end{array}$ & $\begin{array}{l}0.033^{* * *} \\
(0.010)\end{array}$ & $\begin{array}{l}0.028^{* * *} \\
(0.009)\end{array}$ & & & \\
\hline$A Y_{t-2}$ & & & & $\begin{array}{c}0.016^{*} \\
(0.008)\end{array}$ & $\begin{array}{l}0.018^{* *} \\
(0.009)\end{array}$ & $\begin{array}{c}0.015^{*} \\
(0.009)\end{array}$ \\
\hline $\mathrm{FLFP}_{\mathrm{t}-2}$ & $\begin{array}{l}-0.077^{* * *} \\
(0.011)\end{array}$ & $\begin{array}{l}-0.081 * * * \\
(0.011)\end{array}$ & $\begin{array}{l}-0.073^{* * *} \\
(0.011)\end{array}$ & $\begin{array}{l}-0.074^{* * *} \\
(0.010)\end{array}$ & $\begin{array}{l}-0.076^{* * *} \\
(0.011)\end{array}$ & $\begin{array}{l}-0.070^{* * *} \\
(0.011)\end{array}$ \\
\hline Unemployment $_{\mathrm{t}-2}$ & $\begin{array}{l}-0.042 * * * \\
(0.009)\end{array}$ & $\begin{array}{l}-0.042^{* * *} \\
(0.009)\end{array}$ & $\begin{array}{l}-0.039 * * * \\
(0.009)\end{array}$ & $\begin{array}{l}-0.044^{* * *} \\
(0.009)\end{array}$ & $\begin{array}{l}-0.045^{* * *} \\
(0.009)\end{array}$ & $\begin{array}{l}-0.041^{* * *} \\
(0.009)\end{array}$ \\
\hline $\begin{array}{l}\text { Number of } \\
\text { Observations }\end{array}$ & 1,574 & 1,574 & 1,574 & 1,574 & 1,574 & 1,574 \\
\hline
\end{tabular}

Note: Dependent variable: Marriage rates. ${ }^{* * *} p$-value $<0.01,{ }^{* *} p$-value $<0.05$, $* p$-value $<0.1$. FLFP stands for female labour force participation. Decade dummies have been included.

Source: Own calculations employing data extracted from the IPUMS-CPS.

Tab. 5: $\quad$ Dumitrescu/Hurlin (2012) Granger non-causality test

\begin{tabular}{lrrr}
\hline & Both & \multicolumn{1}{c}{ Male } & Female \\
\hline W-bar (Wald statistic) $_{\text {Z-bar (Standardised statistic) }}$ & 31.301 & 31.895 & 26.947 \\
-value $^{\text {a }}$ & 32.953 & 33.793 & 26.795 \\
Critical value (95\%) & 0.008 & 0.033 & 0.001 \\
Z-bar tildeb $^{\text {b }}$ & 105.520 & 87.067 & 58.300 \\
-value $^{\text {a }}$ & 9.754 & 10.043 & 7.642 \\
Critical value (95\%) $^{\text {Optimal number of lags }}{ }^{\mathrm{c}}$ & 0.008 & 0.033 & 0.001 \\
\hline
\end{tabular}

$\mathrm{H}_{0}$ : RY does not Granger-cause marriage.

$\mathrm{H}_{1}$ : RY does Granger-cause marriage for at least one state.

a $p$-value computed using 1,000 bootstrap replications.

b Preferred for large $N$ but relatively small $T$ datasets.

${ }^{c}$ Optimal number of lags selected according to Bayesian (BIC) criterion.

Source: Own calculations employing data extracted from the IPUMS-CPS.

lies at the 5 percent level. Hence, we can reject the null hypothesis of no causality and infer Granger causality for at least one state in all cases presented. 
Tab. 6: $\quad$ Dumitrescu/Hurlin (2012) Granger non-causality test

\begin{tabular}{lrrr}
\hline & Both & Male & Female \\
\hline W-bar (Wald statistic) & 30.771 & 38.551 & 24.041 \\
Z-bar (Standardised statistic) & 32.203 & 43.205 & 22.685 \\
$p$-value & 0.152 & 0.027 & 0.563 \\
Critical value (95\%) $^{\text {a }}$ & 38.034 & 39.152 & 40.713 \\
Z-bar tilde $^{\text {b }}$ & 9.497 & 13.272 & 6.231 \\
$p$-value & 0.152 & 0.027 & 0.563 \\
Critical value (95\%) $^{\text {Optimal number of lags }}{ }^{c}$ & 11.498 & 11.881 & 12.417 \\
\hline
\end{tabular}

$\mathrm{H}_{0}$ : Marriage does not Granger-cause RY.

$\mathrm{H}_{1}$ : Marriage does Granger-cause RY for at least one state.

a $p$-value computed using 1,000 bootstrap replications.

b Preferred for large $N$ but relatively small $T$ datasets.

${ }^{c}$ Optimal number of lags selected according to Bayesian (BIC) criterion.

Source: Own calculations employing data extracted from the IPUMS-CPS.

Table 6 tests for the Granger causal impact of marriage on RY. The $p$-values change and become higher for "Both" and "Female", but the value remains low in the case of "Male". The results therefore show that there is a Granger causal effect of marriage on RY only for young men. That may be explained by the fact that the young men who retreat from marriage have, on average, lower relative income than their peers who get married. A decline in marriage therefore becomes evident as a causal factor on RY. Figure 5 shows the latter. In sum, results indicate that in five out of six cases considered, the Grangrer causal effect is one-directional and runs from RY to marriage.

\subsection{Robustness check}

We proceed to robustness checks by employing three additional methods. First, we start with the Arellano-Bond estimator (difference GMM). A one-step difference GMM estimator has been considered instead of two ${ }^{15}$ due to the lower standard errors obtained in the former. Moreover, in this way we avoid the magnification of the gaps produced by the first difference transformation (see Roodman 2009: 21). It is also important to ensure that the number of instruments is lower than the number of states. We include the number of instruments obtained for each one regression in Table A1.

Next, we correct for cross-sectional dependence (Driscoll/Kraay 1998). Driscoll and Kraay (D-K) standard errors aim to control for "spatial" forms of cross-sectional dependence. The latter is important given the potential of unobserved common

\footnotetext{
$\overline{15}$ For a discussion on the one-step and two-step GMM estimator, see Hwang/Sun (2018).
} 
Fig. 5: Relative income for single and married young men (age 15-24)

Relative income 15-24

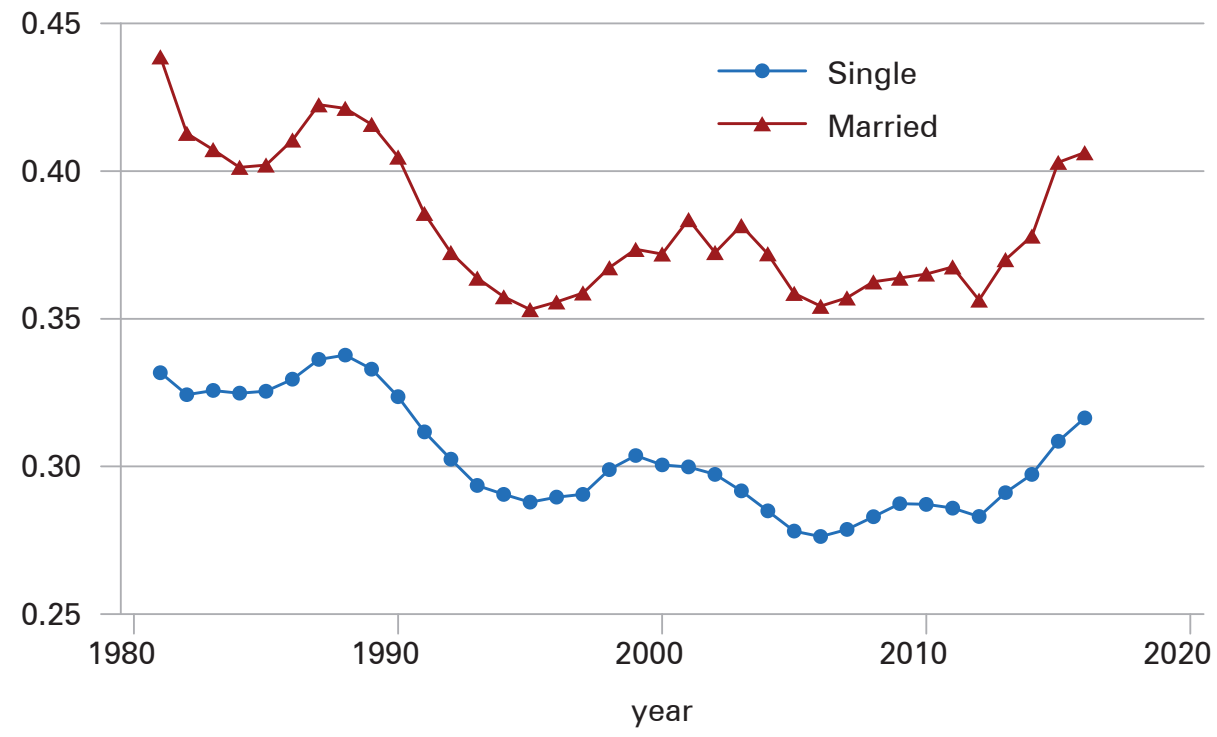

Source: Own calculations employing data extracted from the IPUMS-CPS.

shocks (political, economic, cultural or spatial) across states that could bias the results. Finally, we apply the Blackwell (2005) formula which corrects standard errors for heteroskedastic and contemporaneously correlated disturbances across panels.

The robustness results are presented in the Appendices. In Tables A1, B1 and B2, we present the outcomes for the aforementioned corrections. The results are qualitatively similar to those presented in subsection 5.1. We observe that the coefficient of RY is positive and highly significant as previously. The significance varies depending on the method employed. On the other hand, AY is shown to be statistically significant in all but the GMM estimator (Table A1). Upon comparing RY and $A Y$, it is noted that $R Y$ has the greatest impact on marriage. However, its impact is shown to be less than that of the FLFP and the unemployment rate of young men. The former exerts the most sizeable effect, lending support to the women's emancipation theories. Uncertainty, that the unemployment rate typifies, has the smallest impact.

Finally, in Tables $\mathrm{C} 1$ and $\mathrm{C} 2$, we test for the hypothesis that the obtained results on RY might be considered as spurious due to the educational attainment of young men. In other words, we test whether young men decide to postpone marriage owing to their attendance in higher education rather than their low economic prospects compared with their aspirations. On this purpose, we estimate the RY for young men (15-24 years old) who attained a level of education equal to or more than high school but less than a bachelor's degree, and were full-time, year-round workers 
during the previous year. We follow the same methods as applied in subsection 5.1. In both of the Tables $\mathrm{C} 1$ and $\mathrm{C} 2, \mathrm{RY}$ is still positive and statistically significant. Differences arise only in respect of the remaining variables. AY is insignificant, as is FLFP apart from one case (Table C2, column 2). The young male unemployment variable becomes positive and significant only for the "Male" category in both tables (p-value < 0.05).

\section{Conclusions}

Previous studies have pointed out the importance of the institution of marriage, both for the individual and the well-being of society (Popenoe 2009; Lerman 2011; Halla/Scharler 2012). This paper investigates its decline from the Easterlin relative income perspective. According to Macunovich (2011), there have been two studies in the past testing this hypothesis for marriage. The results contradict each other: one study supports the hypothesis (Macunovich 2002) while the other refutes it (MacDonald/Rindfuss 1981). We contribute to the relevant literature by providing some new evidence. We employ recent data and panel dynamic techniques and show that an increase in the relative income of young men also increases their odds of getting married.

One might question the strength of the results on the ground of cultural effects. Female education has improved in recent decades and the resultant increase in women's emancipation (Guvenen/Rendall 2015) has affected their marriage rates. This paper deals with such effects by incorporating female labour force participation - as a measure of female emancipation - and time decade dummies into the model specification.

RY might also be useful to policy-makers. RY can be modified by either the numerator (income or wage) or by the denominator (family income during childhood). The former could be accommodated through a stabilising macroeconomic policy. For the latter, one could argue that the same applies since the current income of parents is the future "childhood income" of young adults. However, a wage increase would affect "childhood income" inequality, which in turn would be depicted in future RY (in young adulthood). Thus, one has to consider the impact of income inequality over the long term (Genicot/Ray 2017). Richins (2017) found that middle school children especially are engaged in the process of social comparison and this is why "childhood income" inequality becomes important. Therefore, one could make the following statement: the higher the income inequality, the worse the outcome of the comparisons for the less advantaged children, and the higher the materialism they acquire and transfer to their early adulthood. In other words, a young adult might be affected not only by the level of income inequality that he currently faces (as a young adult), but also by that faced in childhood (as a child). Accordingly, this study urges for more research on how children perceive income inequality and how childhood income inequality interacts with current income inequality to shape young adults' demographic behaviour. 
Given the central role of childhood experiences in the Easterlin hypothesis, this paper also tries to add to a growing body of literature that investigates the impact of childhood socioeconomic status on various adulthood outcomes (Tani et al. 2016; Last et al. 2018; Barr et al. 2018; Stamos et al. 2019). A future paper could also study the socioeconomic mobility aspect that comes directly from this hypothesis with respect to marriage.

\section{References}

Akerlof, George A.; Yellen, Janet L.; Katz, Michael L. 1996: An analysis of out-of-wedlock childbearing in the United States. In: The Quarterly Journal of Economics 111,2: 277317. https://doi.org/10.2307/2946680

Angrist, Josh 2002: How do sex ratios affect marriage and labor markets? Evidence from America's second generation. In: The Quarterly Journal of Economics 117,3: 997-1038. https://doi.org/10.1162/003355302760193940

Arellano, Manuel; Bond, Stephen 1991: Some tests of specification for panel data: Monte Carlo evidence and an application to employment equations. In: The Review of Economic Studies 58,2: 277-297. https://doi.org/10.2307/2297968

Barr, Peter B. et al. 2018: Childhood socioeconomic status and longitudinal patterns of alcohol problems: Variation across etiological pathways in genetic risk. In: Social Science \& Medicine 209: 51-58. https://doi.org/10.1016/j.socscimed.2018.05.027

Becker, Gary S. 1991: A Treatise on the Family. Cambridge: Harvard University Press.

Blackwell, J. Lloyd 2005: Estimation and testing of fixed-effect panel-data systems. In: The STATA Journal 5,2: 202-207. https://doi.org/10.1177/1536867X0500500205

Blau, Francine D.; Kahn, Lawrence M. 2007: Changes in the labor supply behavior of married women: 1980-2000. In: Journal of Labor Economics 25,3: 393-438. https://doi.org/10.1086/513416

Born, Benjamin; Breitung, Jörg 2016: Testing for serial correlation in fixed-effects panel data models. In: Econometric Reviews 35,7: 1290-1316. https://doi.org/10.1080/07474938.2014.976524

Bridges, Tristan; Boyd, Melody L. 2016: On the marriageability of men. In: Sociology Compass 10,1: 48-64. https://doi.org/10.1111/soc4.12339

Bronson, Mary Ann; Mazzocco, Maurizio 2018: Cohort size and the marriage market: Explaining nearly a century of changes in US marriage rates. UCLA CCPR Population Working Papers.

Bruno, Giovanni S. 2005a: Approximating the bias of the LSDV estimator for dynamic unbalanced panel data models. In: Economics Letters 87,3: 361-366. http://dx.doi.org/10.1016/j.econlet.2005.01.005

Bruno, Giovanni S. 2005b: Estimation and inference in dynamic unbalanced panel-data models with a small number of individuals. In: The Stata Journal 5,4: 473-500. https://doi.org/10.1177/1536867X0500500401

Buunk, Abraham P.; Gibbons, Frederick X. 2007: Social comparison: The end of a theory and the emergence of a field. In: Organizational Behavior and Human Decision Processes 102,1: 3-21. https://doi.org/10.1016/j.obhdp.2006.09.007

Carrion-i-Silvestre, Josep Lluís; Gadea, María Dolores 2013: GLS-based unit root tests for bounded processes. In: Economics Letters 120,2: 184-187. 
Cavaliere, Giuseppe; Xu, Fang 2014: Testing for unit roots in bounded time series. In: Journal of Econometrics 178: 259-272. https://doi.org/10.1016/j.jeconom.2013.08.026

Cherlin, Andrew J. 1992: Demographic Trends. In Marriage, Divorce, Remarriage. Cambridge, MA: Harvard University Press: 6-30.

Driscoll, John C.; Kraay, Aart C. 1998: Consistent covariance matrix estimation with spatially dependent panel data. In: Review of Economics and Statistics 80,4: 549-560. https://doi.org/10.1162/003465398557825

Dumitrescu, Elena-Ivona; Hurlin, Christophe 2012: Testing for Granger non-causality in heterogeneous panels. In: Economic Modelling 29,4: 1450-1460. https://doi.org/10.1016/j.econmod.2012.02.014

Easterlin, Richard A. 1966: On the relation of economic factors to recent and projected fertility changes. In: Demography 3,1: 131-153. https://doi.org/10.2307/2060068

Easterlin, Richard A. 1987: Birth and fortune: The impact of numbers on personal welfare. University of Chicago Press.

Easterlin, Richard A. 2001: Income and happiness: Towards a unified theory. In: The Economic Journal 111,473: 465-484.

Ermisch, John Francis 1981: Economic opportunities, marriage squeezes and the propensity to marry: an economic analysis of period marriage rates in England and Wales. In: Population Studies 35,3: 347-356. https://doi.org/10.1080/00324728.1981.10404388

Farmer, Roger E. A. 2015: The stock market crash really did cause the great recession. In: Oxford Bulletin of Economics and Statistics 77,5: 617-633. https://doi.org/10.1111/obes.12100

Festinger, Leon 1954: A theory of social comparison processes. In: Human Relations 7,2: 117-140. https://doi.org/10.1177/001872675400700202

Flood, Sarah et al. 2018: Integrated Public Use Microdata Series, Current Population Survey. Current Population Survey: Version. 6.0 [Machine-Readable dataset]. Minneapolis, MN: IPUMS.

Genicot, Garance; Ray, Debraj 2017: Aspirations and inequality. In: Econometrica 85,2: 489-519. https://doi.org/10.3982/ECTA13865

Goldin, Claudia; Katz, Lawrence F. 2002: The power of the pill: Oral contraceptives and women's career and marriage decisions. In: Journal of Political Economy 110,4: 730770. https://doi.org/10.1086/340778

González-Val, Rafael; Marcén, Miriam 2018: Unemployment, marriage and divorce. In: Applied Economics 50,13: 1495-1508. https://doi.org/10.1080/00036846.2017.1366642

Guvenen, Fatih; Rendall, Michelle 2015: Women's emancipation through education: A macroeconomic analysis. In: Review of Economic Dynamics 18,4: 931-956. https://doi.org/10.1016/j.red.2014.11.004

Halla, Martin; Scharler, Johann 2012: Marriage, Divorce, and Interstate Risk Sharing. In: The Scandinavian Journal of Economics 114,1: 55-78. https://doi.org/10.1111/j.1467-9442.2011.01673.x

Hwang, Jungbin; Sun, Yixiao 2018: Should we go one step further? An accurate comparison of one-step and two-step procedures in a generalized method of moments framework. In: Journal of Econometrics 207,2: 381-405. https://doi.org/10.1016/j.jeconom.2018.07.006

Ishizuka, Patrick 2018: The economic foundations of cohabiting couples' union transitions. In: Demography 55,2: 535-557. https://doi.org/10.1007/s13524-018-0651-1 
Khandwala, Yash S. et al. 2017: The age of fathers in the USA is rising: an analysis of 168867480 births from 1972 to 2015. In: Human Reproduction 32,10: 2110-2116. https://doi.org/10.1093/humrep/dex267

Last, Briana S. et al. 2018: Childhood socioeconomic status and executive function in childhood and beyond. In: PloS One 13,8: e0202964.

https://doi.org/10.1371/journal.pone.0202964

Lerman, Robert I. 1996: The impact of the changing US family structure on child poverty and income inequality. In: Economica 63,250: S119-S139. https://doi.org/10.2307/2554812

Lerman, Robert I. 2011: Economic perspectives on marriage: Causes, consequences, and public policy. In: Cohen, Lloyd R.; Wright, Joshua D. (Eds.): Research Handbook on the Economics of Family Law. Cheltenham, UK: Edward Elgar: 72-95.

Lopez, Luciano; Weber, Sylvain 2017: Testing for Granger causality in panel data. In: The Stata Journal 17,4: 972-984. https://doi.org/10.1177/1536867X1801700412

Lutz, Wolfgang; Skirbekk, Vegard; Testa, Maria Rita 2006: The low-fertility trap hypothesis: Forces that may lead to further postponement and fewer births in Europe. In: Vienna Yearbook of Population Research 167-192. https://doi.org/10.1553/populationyearbook2006s167

MacDonald, Maurice M.; Rindfuss, Ronald R. 1981: Earnings, relative income, and family formation. In: Demography 18,2: 123-136. https://doi.org/10.2307/2061088

Macunovich, Diane J. 1997: A conversation with Richard Easterlin. In: Journal of Population Economics 10,2: 119-136. https://doi.org/10.1007/s001480050034

Macunovich, Diane J. 1998a: Fertility and the Easterlin hypothesis: An assessment of the literature. In: Journal of Population Economics 11,1: 53-111. https://doi.org/10.1007/s001480050058

Macunovich, Diane J. 1998b: Race and relative income/price of time effects on US fertility. In: The Journal of Socio-Economics 27,3: 365-401.

Macunovich, Diane J. 2002: Birth Quake: The Baby Boom and Its Aftershocks. Chicago: University of Chicago Press. https://doi.org/10.7208/chicago/9780226500928.001.0001

Macunovich, Diane J. 2011: Re-visiting the Easterlin hypothesis: Marriage in the US 1968-2010. In: SSRN Electronic Journal. https://doi.org/10.2139/ssrn.1906189

Macunovich, Diane J. 2012: Relative cohort size, relative income, and married women's labor force participation: United States, 1968-2010. In: Population and Development Review 38,4: 631-648. https://doi.org/10.1111/j.1728-4457.2012.00530.x

Martin, Steven P.; Astone, Nan Marie; Peters, H. Elizabeth 2014: Fewer Marriages, More Divergence: Marriage Projections for Millennials to Age 40. Washington, DC: Urban Institute.

Mathews, T. J.; Hamilton, Brady E. 2002: Mean age of mother, 1970-2000. In: National Vital Statistics Reports 51,1: 1-14.

Mathews, T. J.; Hamilton, Brady E. 2016: Mean Age of Mothers is on the Rise: United States, 2000-2014. In: NCHS Data Brief 232: 1-8.

McLanahan, Sara 2004: Diverging destinies: How children are faring under the second demographic transition. In: Demography 41,4: 607-627. https://doi.org/10.1353/dem.2004.0033

McLanahan, Sara; Casper, Lynne 1995: Growing diversity and inequality in the American family. In: Farley, Reynolds (Ed.): State of the Union: America in the 1990s. New York: Russell Sage Foundation: 1-46. 
Nickell, Stephen 1981: Biases in dynamic models with fixed effects. In: Econometrica 49: 1417-1426. https://doi.org/10.2307/1911408

Nielsen, Helena Skyt; Smith, Nina; Çelikaksoy, Aycan 2009: The effect of marriage on education of immigrants: Evidence from a policy reform restricting marriage migration. In: Scandinavian Journal of Economics 111,3: 457-486. https://doi.org/10.1111/j.1467-9442.2009.01572.x

Oppenheimer, Valerie Kincade 1988: A theory of marriage timing. In: American Journal of Sociology 94,3: 563-591. https://doi.org/10.1086/229030

Oppenheimer, Valerie Kincade 1997: Women's employment and the gain to marriage: The specialization and trading model. In: Annual Review of Sociology 23,1: 431-453. https://doi.org/10.1146/annurev.soc.23.1.431

Pampel, Fred C.; Peters, H. Elizabeth 1995: The Easterlin effect. In: Annual Review of Sociology 21,1: 163-194. https://doi.org/10.1146/annurev.so.21.080195.001115

Parsons, Talcott 1949: The Social Structure of the Family. In: Ashen, Ruth Nanda (Ed.): The Family: Its Function and Destiny. Oxford: Harper \& Brothers Publishers.

Pesaran, M. Hashem 2007: A simple panel unit root test in the presence of cross-section dependence. In: Journal of Applied Econometrics 22,2: 265-312. https://doi.org/10.1002/jae.951

Pesaran, M. Hashem 2015: Testing weak cross-sectional dependence in large panels. In: Econometric Reviews 34,6-10: 1089-1117. https://doi.org/10.1080/07474938.2014.956623

Pessin, Léa 2018: Changing gender norms and marriage dynamics in the United States. In: Journal of Marriage and Family 80,1: 25-41. https://doi.org/10.1111/jomf.12444

Popenoe, David 2009: Cohabitation, marriage, and child wellbeing: A cross-national perspective. In: Society 46,5: 429-436. https://doi.org/10.1007/s12115-009-9242-5

Richins, Marsha L. 2017: Materialism pathways: The processes that create and perpetuate materialism. In: Journal of Consumer Psychology 27,4: 480-499. https://doi.org/10.1016/j.jcps.2017.07.006

Robinson, William S. 1950: Ecological correlations and the behavior of individuals. In: American Sociological Review 15: 351-357. https://doi.org/10.2307/2087176

Roodman, David 2009: How to doxtabond2: An introductionto difference and system GMM in Stata. In: The Stata Journal 9,1: 86-136. https://doi.org/10.1177/1536867X0900900106

Sass/er, Sharon; Schoen, Robert 1999: The effect of attitudes and economic activity on marriage. In: Journal of Marriage and the Family 61,1: 147-159. https://doi.org/10.2307/353890

Schapiro, Morton Owen 1988: Socio-economic effects of relative income and relative cohort size. In: Social Science Research 17,4: 362-383. https://doi.org/10.1016/0049-089X(88)90009-9

Simpson, Edward H. 1951: The interpretation of interaction in contingency tables. In: Journal of the Royal Statistical Society: Series B (Methodological) 13,2: 238-241. https://doi.org/10.1111/j.2517-6161.1951.tb00088.x

Stamos, Angelos; Altsitsiadis, Efthymios; Dewitte, Siegfried 2019: Investigating the effect childhood socioeconomic background on interpersonal trust: Lower childhood socioeconomic status predicts lower levels of trust. In: Personality and Individual Differences 145: 19-25. https://doi.org/10.1016/j.paid.2019.03.011 
Stevenson, Betsey; Wolfers, Justin 2007: Marriage and divorce: Changes and their driving forces. In: Journal of Economic Perspectives 21,2: 27-52. https://doi.org/10.1257/jep.21.2.27

Sweeney, Megan M. 2002: Two decades of family change: The shifting economic foundations of marriage. In: American Sociological Review 67,1: 132-147. https://doi.org/10.2307/3088937

Tani, Yukako et al. 2016: Childhood socioeconomic status and onset of depression among Japanese older adults: the JAGES prospective cohort study. In: The American Journal of Geriatric Psychiatry 24,9: 717-726. https://doi.org/10.1016/j.jagp.2016.06.001

Upadhyay, Ushma D. et al. 2014: Women's empowerment and fertility: A review of the literature. In: Social Science \& Medicine 115: 111-120. https://doi.org/10.1016/j.socscimed.2014.06.014

Van de Kaa, Dirk J. 1987: Europe's second demographic transition. In: Population Bulletin 42,1: 1-59.

Willoughby, Brian J.; Hall, Scott S.; Goff, Saige 2015: Marriage matters but how much? Marital centrality among young adults. In: The Journal of Psychology 149,8: 796-817. https://doi.org/10.1080/00223980.2014.979128

Willoughby, Brian J.; James, Spencer Lyle 2017: The marriage paradox: Why emerging adults love marriage yet push it aside. Oxford University Press. https://doi.org/10.1093/acprof:oso/9780190296650.001.0001

Wooldridge, Jeffrey M. 2002: Econometric analysis of cross section and panel data. Cambridge, MA: MIT press.

Wursten, Jesse 2018: Testing for serial correlation in fixed-effects panel models. In: The Stata Journal 18,1: 76-100. https://doi.org/10.1177/1536867X1801800106

Dr. Georgios Mavropoulos. Prof. Dr. Theodore Panagiotidis ( $\triangle)$. University of Macedonia, Department of Economic Sciences. Thessaloniki, Greece.

E-mail:mavropoulos@uom.edu.gr, tpanag@uom.edu.gr

URL: https://www.researchgate.net/profile/Georgios-Mavropoulos-2 https://www.uom.gr/en/tpanag 


\section{Appendix}

\section{Appendix A: GMM estimator results}

Tab. A1: GMM first difference estimator

\begin{tabular}{|c|c|c|c|c|c|c|}
\hline & $\begin{array}{c}(1) \\
\text { Both }\end{array}$ & $\begin{array}{c}(2) \\
\text { Male }\end{array}$ & $\begin{array}{c}(3) \\
\text { Female }\end{array}$ & $\begin{array}{c}\text { (4) } \\
\text { Both }\end{array}$ & $\begin{array}{c}(5) \\
\text { Male }\end{array}$ & $\begin{array}{c}\text { (6) } \\
\text { Female }\end{array}$ \\
\hline Marriage $_{t-1}$ & $\begin{array}{l}1.519 * * * \\
(0.341)\end{array}$ & $\begin{array}{l}1.100 * * * \\
(0.290)\end{array}$ & $\begin{array}{l}1.238^{* * *} \\
(0.351)\end{array}$ & $\begin{array}{l}1.718^{* * *} \\
(0.243)\end{array}$ & $\begin{array}{l}1.011 * * * \\
(0.276)\end{array}$ & $\begin{array}{l}1.408^{* * * *} \\
(0.242)\end{array}$ \\
\hline$R Y_{t-2}$ & $\begin{array}{l}0.929 * * \\
(0.461)\end{array}$ & $\begin{array}{c}0.817^{*} \\
(0.412)\end{array}$ & $\begin{array}{c}0.846^{*} \\
(0.459)\end{array}$ & & & \\
\hline$A Y_{t-2}$ & & & & $\begin{array}{c}0.625 \\
(0.390)\end{array}$ & $\begin{array}{c}0.317 \\
(0.614)\end{array}$ & $\begin{array}{c}0.552 \\
(0.388)\end{array}$ \\
\hline FLFP $_{\mathrm{t}-2}$ & $\begin{array}{l}-1.221 * * * \\
(0.219)\end{array}$ & $\begin{array}{l}-0.933^{* * *} \\
(0.195)\end{array}$ & $\begin{array}{l}-1.076^{* * *} \\
(0.234)\end{array}$ & $\begin{array}{l}-0.885^{* * *} \\
(0.205)\end{array}$ & $\begin{array}{l}-0.604^{* * *} \\
(0.158)\end{array}$ & $\begin{array}{l}-0.777^{* * *} \\
(0.202)\end{array}$ \\
\hline Unemployment $_{\mathrm{t}-2}$ & $\begin{array}{l}-1.076^{* * *} \\
(0.311)\end{array}$ & $\begin{array}{l}-1.223^{* * *} \\
(0.325)\end{array}$ & $\begin{array}{l}-1.171^{* * *} \\
(0.304)\end{array}$ & $\begin{array}{l}-0.905^{* * *} \\
(0.239)\end{array}$ & $\begin{array}{l}-1.278^{* * *} \\
(0.309)\end{array}$ & $\begin{array}{l}-1.028^{* * * *} \\
(0.245)\end{array}$ \\
\hline F-stat. (Prob $>$ F) & 0.000 & 0.000 & 0.000 & 0.000 & 0.000 & 0.000 \\
\hline $\begin{array}{l}\text { Number of } \\
\text { instruments }\end{array}$ & 41 & 41 & 41 & 41 & 41 & 41 \\
\hline $\begin{array}{l}\text { Number of } \\
\text { Observations }\end{array}$ & 1,508 & 1,508 & 1,508 & 1,508 & 1,508 & 1,508 \\
\hline
\end{tabular}

Note: Dependent variable: Marriage rates. Instrumental variable: One year lag of the independent. ${ }^{* *} p$-value $<0.01,{ }^{*} p$-value $<0.05, * p$-value $<0.1$. FLFP stands for female labour force participation. Decade dummies have been included.

Source: Own calculations employing data extracted from the IPUMS-CPS. 


\section{Appendix B: Control for cross-sectional dependence (CSD)}

Tab. B1: Control for CSD (D-K s.e.)

\begin{tabular}{lcccccc}
\hline & $\begin{array}{c}(1) \\
\text { Both }\end{array}$ & $\begin{array}{c}(2) \\
\text { Male }\end{array}$ & $\begin{array}{c}(3) \\
\text { Female }\end{array}$ & $\begin{array}{c}(4) \\
\text { Both }\end{array}$ & $\begin{array}{c}(5) \\
\text { Male }\end{array}$ & $\begin{array}{c}(6) \\
\text { Female }\end{array}$ \\
\hline Marriage $_{\mathrm{t}-1}$ & $0.977^{* * *}$ & $0.970^{* * *}$ & $0.970^{* * *}$ & $0.981^{* * *}$ & $0.973^{* * *}$ & $0.974^{* * *}$ \\
& $(0.021)$ & $(0.022)$ & $(0.020)$ & $(0.023)$ & $(0.023)$ & $(0.022)$ \\
$\mathrm{RY}_{\mathrm{t}-2}$ & $0.029^{* *}$ & $0.033^{* * *}$ & $0.028^{*}$ & & & \\
& $(0.014)$ & $(0.011)$ & $(0.016)$ & & & \\
$\mathrm{AY}_{\mathrm{t}-2}$ & & & & $0.016^{* *}$ & $0.019^{* *}$ & $0.015^{*}$ \\
& & & & $(0.008)$ & $(0.009)$ & $(0.009)$ \\
FLFP $_{\mathrm{t}-2}$ & $-0.077^{* *}$ & $-0.081^{* * *}$ & $-0.073^{* *}$ & $-0.073^{* *}$ & $-0.076^{* * *}$ & $-0.070^{* *}$ \\
& $(0.032)$ & $(0.026)$ & $(0.034)$ & $(0.031)$ & $(0.025)$ & $(0.033)$ \\
Unemployment & -0.042 & $-0.042^{*}$ & -0.039 & $-0.044^{*}$ & $-0.045^{*}$ & -0.041 \\
& $(0.025)$ & $(0.023)$ & $(0.026)$ & $(0.026)$ & $(0.023)$ & $(0.026)$ \\
Constant & $0.060^{* * *}$ & $0.065^{* * *}$ & $0.064^{* * *}$ & $0.062^{* * *}$ & $0.068^{* * *}$ & $0.067^{* * *}$ \\
& $(0.014)$ & $(0.016)$ & $(0.015)$ & $(0.014)$ & $(0.016)$ & $(0.015)$ \\
R-squared & 0.955 & 0.963 & 0.965 & 0.955 & 0.962 & 0.965 \\
Number of & & & & & & \\
Observations & 1,574 & 1,574 & 1,574 & 1,574 & 1,574 & 1,574 \\
\hline
\end{tabular}

Note: Dependent variable: Marriage rates. Driscoll-Kraay s.e. in parentheses. *** $p$-value $<0.01,{ }^{* *} p$-value $<0.05, * p$-value $<0.1$. FLFP stands for female labour force participation. Decade dummies have been included.

Source: Own calculations employing data extracted from the IPUMS-CPS. 
Tab. B2: Blackwell (2005) panel corrected s.e.

\begin{tabular}{lcccccc}
\hline & $\begin{array}{c}(1) \\
\text { Both }\end{array}$ & $\begin{array}{c}(2) \\
\text { Male }\end{array}$ & $\begin{array}{c}(3) \\
\text { Female }\end{array}$ & $\begin{array}{c}(4) \\
\text { Both }\end{array}$ & $\begin{array}{c}(5) \\
\text { Male }\end{array}$ & $\begin{array}{c}(6) \\
\text { Female }\end{array}$ \\
\hline Marriage $_{\mathrm{t}-1}$ & $0.956^{* * *}$ & $0.942^{* * *}$ & $0.957^{* * *}$ & $0.974^{* * *}$ & $0.959^{* * *}$ & $0.973^{* * *}$ \\
& $(0.031)$ & $(0.026)$ & $(0.032)$ & $(0.032)$ & $(0.026)$ & $(0.032)$ \\
$\mathrm{RY}_{\mathrm{t}-2}$ & $0.051^{* *}$ & $0.053^{* *}$ & $0.050^{* *}$ & & & \\
& $(0.024)$ & $(0.023)$ & $(0.024)$ & & & \\
$\mathrm{AY}_{\mathrm{t}-2}$ & & & & $0.043^{* *}$ & $0.043^{* *}$ & $0.039^{*}$ \\
& & & & $(0.020)$ & $(0.019)$ & $(0.020)$ \\
$\mathrm{FLFP}_{\mathrm{t}-2}$ & $-0.080^{* * *}$ & $-0.077^{* * *}$ & $-0.083^{* * *}$ & $-0.082^{* * *}$ & $-0.078^{* * *}$ & $-0.084^{* * *}$ \\
& $(0.027)$ & $(0.024)$ & $(0.028)$ & $(0.027)$ & $(0.025)$ & $(0.028)$ \\
Unemployment & $-0.067^{* * *}$ & $-0.067^{* * *}$ & $-0.067^{* * *}$ & $-0.066^{* * *}$ & $-0.065^{* * *}$ & $-0.066^{* * *}$ \\
& $(0.026)$ & $(0.024)$ & $(0.026)$ & $(0.026)$ & $(0.023)$ & $(0.026)$ \\
Constant & $0.072^{*}$ & $0.077^{* *}$ & $0.076^{*}$ & 0.062 & $0.068^{*}$ & 0.068 \\
& $(0.040)$ & $(0.034)$ & $(0.041)$ & $(0.042)$ & $(0.036)$ & $(0.044)$ \\
R-squared & 0.937 & 0.928 & 0.938 & 0.937 & 0.928 & 0.938 \\
Number of & & & & & & \\
Observations & 1,574 & 1,574 & 1,574 & 1,574 & 1,574 & 1,574 \\
\hline
\end{tabular}

Note: Dependent variable: Marriage rates. $*^{* *} p$-value $<0.01, *^{*} p$-value $<0.05$, ${ }^{*} p$-value $<0.1$. FLFP stands for female labour force participation. Decade dummies have been included.

Source: Own calculations employing data extracted from the IPUMS-CPS. 
Appendix C: Results for the young men attaining a medium level of education (equal to or more than high school and less than a bachelor's degree)

Tab. C1: Panel dynamic FE estimator

\begin{tabular}{|c|c|c|c|c|c|c|}
\hline & $\begin{array}{c}\text { (1) } \\
\text { Both }\end{array}$ & $\begin{array}{c}(2) \\
\text { Male }\end{array}$ & $\begin{array}{c}(3) \\
\text { Female }\end{array}$ & $\begin{array}{c}\text { (4) } \\
\text { Both }\end{array}$ & $\begin{array}{c}(5) \\
\text { Male }\end{array}$ & $\begin{array}{c}(6) \\
\text { Female }\end{array}$ \\
\hline Marriage $_{t-1}$ & $\begin{array}{l}0.891 * * * \\
(0.014)\end{array}$ & $\begin{array}{l}0.907^{* * *} \\
(0.018)\end{array}$ & $\begin{array}{l}0.884^{* * *} \\
(0.015)\end{array}$ & $\begin{array}{l}0.899 * * * \\
(0.014)\end{array}$ & $\begin{array}{l}0.910 * * * \\
(0.017)\end{array}$ & $\begin{array}{l}0.892^{* * * *} \\
(0.015)\end{array}$ \\
\hline$R Y_{t-2}$ & $\begin{array}{l}0.040^{* *} \\
(0.019)\end{array}$ & $\begin{array}{l}0.033^{*} \\
(0.017)\end{array}$ & $\begin{array}{l}0.047^{* *} \\
(0.021)\end{array}$ & & & \\
\hline$A Y_{t-2}$ & & & & $\begin{array}{l}0.004 \\
(0.011)\end{array}$ & $\begin{array}{c}0.001 \\
(0.009)\end{array}$ & $\begin{array}{c}0.012 \\
(0.012)\end{array}$ \\
\hline $\mathrm{FLFP}_{\mathrm{t}-2}$ & $\begin{array}{l}-0.009 \\
(0.012)\end{array}$ & $\begin{array}{l}-0.018 \\
(0.011)\end{array}$ & $\begin{array}{l}-0.006 \\
(0.013)\end{array}$ & $\begin{array}{l}-0.007 \\
(0.011)\end{array}$ & $\begin{array}{l}-0.016 \\
(0.011)\end{array}$ & $\begin{array}{l}-0.004 \\
(0.013)\end{array}$ \\
\hline Unemployment $_{\mathrm{t}-2}$ & $\begin{array}{c}0.008 \\
(0.007)\end{array}$ & $\begin{array}{l}0.016^{* *} \\
(0.007)\end{array}$ & $\begin{array}{c}0.007 \\
(0.008)\end{array}$ & $\begin{array}{c}0.006 \\
(0.008)\end{array}$ & $\begin{array}{c}0.014 * \\
(0.007)\end{array}$ & $\begin{array}{c}0.004 \\
(0.008)\end{array}$ \\
\hline Constant & $\begin{array}{c}0.006 \\
(0.015)\end{array}$ & $\begin{array}{l}-0.003 \\
(0.018)\end{array}$ & $\begin{array}{c}0.010 \\
(0.015)\end{array}$ & $\begin{array}{c}0.017 \\
(0.016)\end{array}$ & $\begin{array}{l}0.009 \\
(0.017)\end{array}$ & $\begin{array}{c}0.020 \\
(0.017)\end{array}$ \\
\hline $\begin{array}{l}\text { Number of } \\
\text { Observations }\end{array}$ & 1,059 & 1,059 & 1,059 & 1,059 & 1,059 & 1,059 \\
\hline
\end{tabular}

Note: Dependent variable: Marriage rates. $* * * p$-value $<0.01, * * p$-value $<0.05$, ${ }^{*} p$-value $<0.1$. FLFP stands for female labour force participation. Decade dummies have been included.

Source: Own calculations employing data extracted from the IPUMS-CPS. 
Tab. C2: Bias-corrected FE estimator

\begin{tabular}{|c|c|c|c|c|c|c|}
\hline & $\begin{array}{c}\text { (1) } \\
\text { Both }\end{array}$ & $\begin{array}{c}(2) \\
\text { Male }\end{array}$ & $\begin{array}{c}\text { (3) } \\
\text { Female }\end{array}$ & $\begin{array}{c}\text { (4) } \\
\text { Both }\end{array}$ & $\begin{array}{c}(5) \\
\text { Male }\end{array}$ & $\begin{array}{c}(6) \\
\text { Female }\end{array}$ \\
\hline Marriage $_{t-1}$ & $\begin{array}{l}0.891^{* * *} \\
(0.015)\end{array}$ & $\begin{array}{l}0.907^{* * *} \\
(0.014)\end{array}$ & $\begin{array}{l}0.884^{* * *} \\
(0.015)\end{array}$ & $\begin{array}{l}0.899 * * * \\
(0.015)\end{array}$ & $\begin{array}{l}0.910^{* * *} \\
(0.014)\end{array}$ & $\begin{array}{l}0.892^{* * *} \\
(0.015)\end{array}$ \\
\hline$R Y_{t-2}$ & $\begin{array}{l}0.040^{* * *} \\
(0.013)\end{array}$ & $\begin{array}{l}0.033^{* * *} \\
(0.012)\end{array}$ & $\begin{array}{l}0.048^{* * *} \\
(0.014)\end{array}$ & & & \\
\hline$A Y_{t-2}$ & & & & $\begin{array}{c}0.004 \\
(0.010)\end{array}$ & $\begin{array}{c}0.002 \\
(0.009)\end{array}$ & $\begin{array}{c}0.012 \\
(0.011)\end{array}$ \\
\hline FLFP $_{\mathrm{t}-2}$ & $\begin{array}{l}-0.009 \\
(0.010)\end{array}$ & $\begin{array}{l}-0.018 * \\
(0.010)\end{array}$ & $\begin{array}{l}-0.006 \\
(0.011)\end{array}$ & $\begin{array}{l}-0.007 \\
(0.014)\end{array}$ & $\begin{array}{l}-0.017^{*} \\
(0.010)\end{array}$ & $\begin{array}{l}-0.004 \\
(0.011)\end{array}$ \\
\hline Unemployment $t_{t-2}$ & $\begin{array}{c}0.008 \\
(0.007)\end{array}$ & $\begin{array}{l}0.016^{* *} \\
(0.010)\end{array}$ & $\begin{array}{c}0.007 \\
(0.007)\end{array}$ & $\begin{array}{c}0.006 \\
(0.007)\end{array}$ & $\begin{array}{c}0.014^{* *} \\
(0.006)\end{array}$ & $\begin{array}{c}0.004 \\
(0.007)\end{array}$ \\
\hline Number of & & & & & & \\
\hline Observations & 1,059 & 1,059 & 1,059 & 1,059 & 1,059 & 1,059 \\
\hline
\end{tabular}

Note: Dependent variable: Marriage rates. ${ }^{* * *} p$-value $<0.01,{ }^{* *} p$-value $<0.05$, ${ }^{*} p$-value $<0.1$. FLFP stands for female labour force participation. Decade dummies have been included.

Source: Own calculations employing data extracted from the IPUMS-CPS. 


\section{Appendix D: Panel tests}

Tab. D1: Pesaran (2015) cross-sectional dependence test

\begin{tabular}{lrcccc}
\hline Variable & CD-test & $p$-value & Average joint T & Mean $\rho$ & Mean abs $(\rho)$ \\
\hline Marriage (b) & 178.121 & 0.000 & 34.10 & 0.91 & 0.91 \\
Marriage (m) & 166.213 & 0.000 & 34.10 & 0.85 & 0.85 \\
Marriage (f) & 178.597 & 0.000 & 34.10 & 0.91 & 0.91 \\
Relative Income & 74.157 & 0.000 & 34.10 & 0.38 & 0.43 \\
Absolute Income & 26.631 & 0.000 & 34.10 & 0.13 & 0.31 \\
FLFP & 144.385 & 0.000 & 34.10 & 0.74 & 0.74 \\
Unemployment & 64.245 & 0.000 & 34.10 & 0.33 & 0.42 \\
\hline
\end{tabular}

Note: $\mathrm{H}_{0}$ : Cross-section independence; f: female, $\mathrm{m}$ : male, b: both male and female. Source: Own calculations employing data extracted from the IPUMS-CPS.

Tab. D2: Wursten (2018) first order serial correlation test

\begin{tabular}{lccc}
\hline Case & Variable & HR-stat $^{\mathrm{a}}$ & $p$-value \\
\hline Marriage (b) & Residual & 9.06 & 0.000 \\
Marriage (m) & Residual & 6.42 & 0.000 \\
Marriage (f) & Residual & 9.06 & 0.000 \\
\hline
\end{tabular}

Note: f: female, m: male, b: both male and female. $\mathrm{H}_{0}$ : No first-order serial correlation. a Heteroskedasticity-robust (Born/Breitung 2016) HR-test on residuals.

Source: Own calculations employing data extracted from the IPUMS-CPS. 


\section{Comparative Population Studies}

WWW.comparativepopulationstudies.de

ISSN: 1869-8980 (Print) - 1869-8999 (Internet)

\section{Published by}

Federal Institute for Population Research (BiB)

D-65180 Wiesbaden / Germany

\section{Managing Publisher}

Dr. Nikola Sander

\section{(cc) BY-SA}

2022

\section{Editor}

Prof. Frans Willekens

\section{Managing Editor}

Dr. Ralina Panova

Dr. Katrin Schiefer

\section{Editorial Assistant}

Beatriz Feiler-Fuchs

Wiebke Hamann

\author{
Layout \\ Beatriz Feiler-Fuchs \\ E-mail: cpos@bib.bund.de
}

\section{Board of Reviewers}

Bruno Arpino (Barcelona)

Kieron Barclay (Rostock)

Laura Bernardi (Lausanne)

Gabriele Doblhammer (Rostock)

Anette Eva Fasang (Berlin)

Michael Feldhaus (Oldenburg)

Tomas Frejka (Sanibel)

Alexia Fürnkranz-Prskawetz (Vienna)

Birgit Glorius (Chemnitz)

Fanny Janssen (Groningen)

Frank Kalter (Mannheim)

Stefanie Kley (Hamburg)

Bernhard Köppen (Koblenz)

Anne-Kristin Kuhnt (Duisburg)

Hill Kulu (St Andrews)

Nadja Milewski (Wiesbaden)

Roland Rau (Rostock)

Thorsten Schneider (Leipzig)

Tomas Sobotka (Vienna)

Jeroen J. A. Spijker (Barcelona)

Heike Trappe (Rostock)

Helga de Valk (The Hague)

Sergi Vidal (Barcelona)

Michael Wagner (Cologne)

\section{Scientific Advisory Board}

Karsten Hank (Cologne)

Ridhi Kashyap (Oxford)

Michaela Kreyenfeld (Berlin)

Natalie Nitsche (Rostock)

Zsolt Spéder (Budapest)

Alyson van Raalte (Rostock)

Rainer Wehrhahn (Kiel) 